\title{
Eliminating Zygotic Seedlings in 'Turpentine' Mango Rootstock Populations by Visual Roguing
}

\author{
R.J. Schnell, R.J. Knight, and D.M. Harkins \\ U.S. Department of Agriculture, Agricultural Research Service, National \\ Clonal Germplasm Repository, 13601 Old Cutler Road, Miami, FL 33158
}

Gary Zill

Zill High Performance Plants, 6801 107th Place South, Boynton Beach, FL 33437

Additional index words. Mangifera indica

\begin{abstract}
The ability to eliminate zygotic seedlings from the polyembryonic mango (Mangifera indica L.) rootstock 'Turpentine' by visual roguing was investigated. Four selected populations, A) randomly selected plants, B) plants selected as off-types, C) seedlings that were of 'Turpentine' phenotype, and D) seeds where a single seedling emerged, were examined using electrophoretic analysis and five enzyme systems. Significant differences $\left(\chi^{2}=39.63, P<0.001\right)$ were found among the four categories, with $28 \%$ of the random, $66 \%$ of the off-type, $10 \%$ of the true-to-type, and $54 \%$ of the monoembryonic seedlings being zygotic. These data indicate that visual selection for trueness-to-type and roguing for off-types is useful in reducing the frequency of zygotic seedlings among 'Turpentine' rootstock plants.
\end{abstract}

The effect of zygotic seedlings as rootstock on commercial mango production is unknown. Mango rootstock are generally propagated from open-pollinated seed of polyembryonic cultivars and are presumably nucellar in origin (Knight, 1970). Variation for phenotypic traits such as leaf size, leaf shape, flesh color, vigor, and stem color have been observed in open-pollinated seedlings from polyembryonic cultivars (Gazit and Knight, 1989). Visually off-type plants are usually considered to be zygotic in origin; commercial nurseries commonly rogue them out before grafting. The advantages of roguing have not been investigated; however, a more uniform population of rootstock is usually expected to produce a more uniform population of orchard trees.

Degani et al. (1990) developed and characterized six isozyme systems for mango. Schnell and Knight (1992) used five enzyme systems to estimate the percentage of zygotic individuals in seedling populations of five polyembryonic rootstock cultivars. Significant differences were detected for the percentage of off-types occurring in the populations observed. There were $24 \%$ zygotic seedlings in the 'Turpentine' population. Recently, Degani et al. (1992) performed a similar study; they found $20 \%$ of the seedlings in open-pollinated 'Turpentine' to be zygotic. Anderson et al. (1991 ) used isozyme analysis to estimate the success of visual roguing in citrus, where

Received for publication 30 July 1993. Accepted for publication 10 Nov. 1993. The cost of publishing this paper was defrayed in part by the payment of page charges. Under postal regulations, this paper therefore must be hereby marked advertisement solely to indicate this fact. nucellar seedlings also are used as rootstock. Their results demonstrated the ability to significantly reduce the number of zygotic seedlings, although complete elimination was not always possible.

The ability to rogue zygotic individuals visually from a rootstock population would increase plant uniformity and contribute to dependable scion performance. Our objective was to determine if visual roguing could reduce the number of zygotic mango plants in seedling populations of polyembryonic rootstock.

\section{Materials and Methods}

The base population for selection consisted of 1200 'Turpentine' seedlings from openpollinated seeds that had been collected in Mar. 1991 from 12 trees in a field near Black River, Jamaica. This field has been the source of rootstock seed for the Zill commercial nursery for $>10$ years. There are no other mango trees within $1.7 \mathrm{~km}$ of these rootstock mother trees. Seeds were planted in containers, one seed per container, and the seedlings thinned to the largest seedling that emerged; this is standard commercial practice because it is more expensive to break off and replant multiple seedlings emerging from a single seed than it is to plant an abundance of seeds and thin to the largest one.

On 22 May 1991, when the plants were 4 weeks old, 50 individual plants were selected from the 1200 seedlings for each of four groups. A) Seedlings selected at random. This group serves as a subsample of the total population of 1200 single seedlings. Population A estimates the percentage of zygotic seedlings that would normally be found in a base population pro- duced in this manner. B) Visually off-type seedlings. These seedlings would normally be rogued out in a commercial nursery based on leaf shape, leaf size, vigor, and stem color. The difference between the number of zygotic seedlings in population A and B estimates off-type roguing efficiency. C) Seedlings of the 'Turpentine' phenotype. Selection was based on leaf shape, leaf size, vigor, and stem color. This population serves as another estimate of the ability to reduce the number of zygotic seedlings in the base population by selecting for the 'Turpentine' phenotype. Comparing the frequency of zygotic seedlings with the estimate from population A will allow evaluation of the success of selection. This population also serves as a check on the estimate from population B. D) Seed that produced only one seedling. These plants were not selected for true-to-type or off-types. Knowing the number of zygotic seedlings in population would be useful in a rootstock breeding program.

Immature leaf tissue of each of the 200 seedlings was collected from Sept. to Dec. 1991 as fresh flushes became available. We performed extraction and electrophoresis procedures in the same manner as Schnell and Knight (1992). The seedlings were assayed for the following enzyme systems: isocitrate dehydrogenase (IDH) (EC 1.1.1.42), leucine aminopeptidase (LAP) (EC 3.4.11.1), glucose6-phosphate isomerase (GPI) (EC 5.3.1.9), phosphoglucomutase (PGM) (EC 2.7.5.1), and triosephosphate isomerase (TPI) (EC 5.3.1.1).

The seedlings were classified as maternal (nucellar) or off-type (zygotic) based on the isozyme phenotype. We calculated a contingency table and estimated chi-square values (Snedecor and Cochran, 1967). Observed differences in off-type frequencies between groups were significant $\left(\chi^{2}=39.63,3 \mathrm{df}\right.$, and $P<0.001)$.

\section{Results and Discussion}

A total of 14 seedlings (28\%) in population A were zygotic, which approximates earlier findings with 'Turpentine' (Degani et al., 1992; Schnell and Knight, 1992). Using the estimate from population $\mathrm{A}, \approx 336$ of the 1200 plants in the base population would be expected to be zygotic seedlings.

In population B (off-type), 33 zygotic plants $(66 \%)$ were found. If 14 zygotic plants were expected to occur in population $\mathrm{B}$, based on the estimate from population $\mathrm{A}$, the increase of 19 zygotic individuals, or $58 \%$ of the 33 , would have been due to selection. Each plant in this population was phenotypically different from 'Turpentine' for at least some of the characters observed. When the plants were identical to 'Turpentine' for the five enzyme loci, they were considered to be nucellar seedlings; 17 seedlings appearing to be off-types were in this category.

Five plants $(10 \%)$ in population C (true-totype) were zygotic. If 14 zygotic individuals were expected in this population, based on the estimate from population $\mathrm{A}$, the reduction from 14 to 5 zygotic individuals would have been due to selection. The fact that $10 \%$ of the 
seedlings in this group were zygotic and looked identical to nucellar seedlings indicates that it is not always possible to detect a zygotic seedling using phenotypic characters.

Of population $\mathrm{D}$ (monoembryonic), 27 plants $(54 \%)$ were zygotic; therefore, commercial nurseries should discard any seedlings that arise from apparently monoembryonic seed. These seedlings would probably be unacceptable as rootstock. The estimate of the frequency of zygotic plants is useful in our rootstock breeding program because effective population sizes for new rootstock selection can be estimated more accurately.

Selection for true-to-type plants was the most effective method in reducing the number of zygotic seedlings in the base population.
'Turpentine' is heterozygous at four of the five loci scored. On self-pollination, 94\% of the zygotic seedlings likely would be detected using these enzymes. The difference between population B (66\% zygotic seedlings) and population $\mathrm{C}$ ( $90 \%$ nucellar seedlings) maybe due to the limited number of loci scored; however, the 17 nucellar plants in population B differed from the 'Turpentine' phenotype. The five zygotic seedlings in population $\mathrm{C}$ looked like 'Turpentine'.

Electrophoretic analysis revealed one allele $(B)$ at the LAP-1 locus that was not present in the maternal parent. Twenty-two $(27.5 \%)$ of the zygotic seedlings were heterozygous $(A B)$ at this locus and, thus, originated from outcrossing (Table 1). The pollen source for these

Table 1. Isozyme phenotypes of 22 out-crossed zygotic seedlings of 'Turpentine' mango.

\begin{tabular}{|c|c|c|c|c|c|}
\hline \multirow[b]{2}{*}{ Plant no. } & \multicolumn{5}{|c|}{ Locus $^{2}$} \\
\hline & GPI-2 & IDH & LAP-1 & PGM-I & TPI-1 \\
\hline Turp & $\mathrm{AC}$ & $\mathrm{AC}$ & $\overline{\mathrm{AA}}$ & $\mathrm{AC}$ & $\mathrm{AB}$ \\
\hline A4 & AA & $\mathrm{AC}$ & $\mathrm{AB}$ & $\mathrm{CC}$ & $00^{y}$ \\
\hline A29 & $\mathrm{AA}$ & $\mathrm{CC}$ & $A B$ & $\mathrm{AC}$ & 00 \\
\hline A33 & AA & $\mathrm{AC}$ & $\mathrm{AB}$ & AA & $\mathrm{AB}$ \\
\hline A43 & $\mathrm{AA}$ & $\mathrm{AC}$ & $A B$ & 00 & $\mathrm{AB}$ \\
\hline A50 & $\mathrm{AC}$ & $\mathrm{AC}$ & $\mathrm{AB}$ & $\mathrm{CC}$ & $\mathrm{AB}$ \\
\hline B9 & AA & $\mathrm{AC}$ & $\mathrm{AB}$ & $\mathrm{CC}$ & BB \\
\hline B10 & AA & $\mathrm{CC}$ & $\mathrm{AB}$ & 00 & AB \\
\hline B24 & AA & $\mathrm{CC}$ & $\mathrm{AB}$ & AA & AB \\
\hline B25 & AA & $\mathrm{CC}$ & $\mathrm{AB}$ & AA & $\mathrm{AB}$ \\
\hline B34 & AA & $\mathrm{CC}$ & $\mathrm{AB}$ & $\mathrm{AC}$ & $\mathrm{AB}$ \\
\hline B36 & $\mathrm{AA}$ & $\mathrm{AC}$ & $\mathrm{AB}$ & AA & $\mathrm{AB}$ \\
\hline B38 & AA & $\mathrm{AC}$ & $\mathrm{AB}$ & $\mathrm{AC}$ & $\mathrm{AB}$ \\
\hline B43 & AA & $\mathrm{AC}$ & $\mathrm{AB}$ & $\mathrm{AC}$ & AB \\
\hline B47 & AA & $\mathrm{AC}$ & AB & $\mathrm{AC}$ & BB \\
\hline $\mathrm{C} 16$ & AA & $\mathrm{AA}$ & $\mathrm{AB}$ & $\mathrm{AC}$ & $\mathrm{AB}$ \\
\hline $\mathrm{C} 19$ & $\mathrm{AA}$ & $\mathrm{AA}$ & $\mathrm{AB}$ & $\mathrm{AC}$ & $\mathrm{AB}$ \\
\hline $\mathrm{C} 27$ & AA & $\mathrm{AC}$ & $\mathrm{AB}$ & $\mathrm{AC}$ & $\mathrm{AB}$ \\
\hline $\mathrm{C} 29$ & AA & $\mathrm{CC}$ & $\mathrm{AB}$ & $\mathrm{AC}$ & AB \\
\hline C31 & $\mathrm{AA}$ & $\mathrm{AC}$ & $\mathrm{AB}$ & $\mathrm{AC}$ & AB \\
\hline $\mathrm{C} 41$ & AA & $\mathrm{AC}$ & $A B$ & 00 & $\mathrm{AB}$ \\
\hline C50 & AA & $\mathrm{AC}$ & $\mathrm{AB}$ & $\mathrm{AC}$ & 00 \\
\hline D25 & AA & $\mathrm{CC}$ & $\mathrm{AB}$ & 00 & AB \\
\hline
\end{tabular}

${ }^{2} \mathrm{GPI}=$ glucose-6-phosphate isomerase, $\mathrm{IDH}=$ isocitrate dehydrogenase, $\mathrm{LAP}=$ leucine aminopeptidase, PGM $=$ phosphoglucomutase, and TPI = triosephosphate isomerase.

${ }^{y_{00}}=$ Isozyme phenotype not determined.

Table 2. Single locus goodness-of-fit test for 58 zygotic seedlings based on self-pollination of 'Turpentine' mango.

\begin{tabular}{lrcrrr}
\hline \hline Locus $^{2}$ & \multicolumn{1}{c}{ Expected } & & & \\
ratio & $\chi^{2}$ & df & $P$ \\
\hline GPI-2 & $9 \mathrm{AA}: 36 \mathrm{AC}: 13 \mathrm{CC}$ & $1: 2: 1$ & 3.931 & 2 & 0.140 \\
IDH & $13 \mathrm{AA}: 24 \mathrm{AC}: 20 \mathrm{CC}$ & $1: 2: 1$ & 3.140 & 2 & 0.208 \\
PGM-1 & $14 \mathrm{AA}: 24 \mathrm{AC}: 15 \mathrm{CC}$ & $1: 2: 1$ & 0.509 & 2 & 0.775 \\
TPI-1 & 0 AA : 41 AB : $: 8 \mathrm{BB}$ & $1: 2: 1$ & 24.836 & 2 & 0.001 \\
\hline
\end{tabular}

${ }^{\mathrm{z}} \mathrm{GPI}=$ glucose-6-phosphate isomerase, $\mathrm{IDH}=$ isocitrate dehydrogenase, $\mathrm{PGM}=$ phosphoglucomutase, and $\mathrm{TPI}=$ triosephosphate isomerase. seedlings is unknown; the mother trees are isolated from other mango trees. Information on how far pollen can be transported by pollinators (usually flies) is not available in mango. The other 58 zygotic seedlings could have arisen from self-pollination or from crosspollination with a parent of identical genotype for LAP-1 (data not shown).

Using the Linkage-1 program (Suiter et al. 1983) to analyze segregation ratios among the 58 zygotic seedlings that could have resulted from selfing, we found the expected ratios for GPI-2, IDH, and PGM-1, but we found significant deviation for TPI (Table 2). Twentyseven genotypic classes should result on selfpollination for the three loci that were segregating normally. Of these, 21 were found among the 58 seedlings.

Visual roguing reduced the. number of zygotic seedlings from that found in the base population. Selection for true-to-type plants was more successful in reducing zygotic seedlings than selection for off-type plants. Either method would reduce the number of zygotic seedlings in-the base population. Visual roguing of open pollinated 'Turpentine' seedlings is recommended in commercial mango nurseries as an effective method of reducing the number of zygotic seedlings.

\section{Literature Cited}

Anderson, C.M., W.S. Castle, and G.A. Moore. 1991. Isozymic identification of zygotic seedlings in Swingle citrumelo Citrus paradisi $\times$ Poncirus trifoliatanursery and field populations. J. Amer. Soc. Hort. Sci 116:322-326.

Degani, C., M. Cohen, O. Reuveni, R. E1-Batsri, and S. Gazit. 1992. Frequency and characteristics of zygotic seedlings from polyembryonic mango cultivars determined using isozymes as genetic markers. Acta Hort. 341:78-85.

Degani, C., R. El-Batsri, and S. Gazit. 1990. Enzyme polymorphism in mango. J. Amer. Soc. Hort. Sci. 115:844-847.

Gazit, S. and R.J. Knight. 1989. Asexual embryogenesis in mango. Bard Project Rpt. I p. 255280.

Knight, R.J. 1970. Polyembryonic mangos: Their unrealized potential. Proc. Trop. Reg. Amer. Soc. Hort. Sci. 14:145-155.

Schnell, R.J. and R.J. Knight. 1992. Frequency of zygotic seedlings from five polyembryonic mango rootstock. HortScience 27:174-176.

Snedecor, G.W. and W.G. Cochran. 1967. Statistical methods. The Iowa Univ. Press, Ames.

Suiter, K.A., J.F. Wendel, and J.S. Case. 1983. Linkage- 1: A computer program for the detection and analysis of genetic linkage. J. Hered. 74:203-204. 